\title{
Keberdayaan Transmigran dalam Berusahatani di Kabupaten Banyuasin dan Ogan Ilir Provinsi Sumatera Selatan
}

\author{
The Transmigrants' Empowerment in Farming \\ in Banyuasin and Ogan Ilir Regencies, South Sumatera Province
}

\author{
Malta $^{1}$, Sumardjo ${ }^{2}$, Anna Fatchiya ${ }^{2}$, Djoko Susanto ${ }^{2}$ \\ ${ }^{1}$ Program Studi Agribisnis FMIPA, Universitas Terbuka, Tangerang Selatan \\ ${ }^{2}$ Departemen Sains Komunikasi dan Pengembagan Masyarakat, Fakultas Ekologi Manusia, \\ Institut Pertanian Bogor, Bogor
}

\begin{abstract}
The development of communities and transmigration areas should be designed within the framework of making transmigration communities empowered in carrying out their business activities to attain a welfare level. Empowerment is the basic element that allows a community to survive in developing itself to achieve progress. The objectives of the research were to analyze the level of transmigrants' empowerment in farming and the dominant factors affecting the transmigrants' empowerment in farming. The study was conducted from May 2016 to January 2017. The total population was 3,537 transmigrant households, and the size of the sample in this study was determined by using the Slovin formula. The number of samples was 359 respondents, using the stratified random sampling. The research data consisted of primary data and secondary data. The primary data were obtained through structured interviews, in-depth interviews, and field observations. The influence of variables was tested using SEM (Structural Equation Modelling). The results of the study showed that the level of the transmigrants' empowerment in farming was in a low category. The factors affecting the empowerment were the availability of support factors, socio-cultural support, extension activities, training of prospective transmigrants, and individual characteristics of transmigrants.
\end{abstract}

Keywords: transmigrants, empowerment, farming, transmigration, welfare

\begin{abstract}
Abstrak
Pengembangan masyarakat dan kawasan transmigrasi seharusnya dirancang dalam kerangka untuk menjadikan masyarakat transmigrasi berdaya dalam menjalankan kegiatan usahanya, sehingga tercapai kesejahteraan. Keberdayaan merupakan unsur dasar yang memungkinkan suatu masyarakat dapat bertahan dalam mengembangkan diri untuk mencapai kemajuan. Tujuan penelitian adalah menganalisis tingkat keberdayaan transmigran dalam berusahatani dan faktor-faktor yang dominan memengaruhi keberdayaan transmigran dalam berusahatani. Penelitian dilakukan mulai Mei 2016 sampai Januari 2017. Jumlah populasi adalah 3.537 rumah tangga transmigran. Besarnya sampel dalam penelitian ini ditentukan dengan menggunakan rumus Slovin. Jumlah sampel sebanyak 359 responden. Penarikan sampel secara acak berstrata (stratified random sampling). Data penelitian terdiri dari data primer dan data sekunder. Data primer diperoleh melalui wawancara terstruktur, wawancara mendalam, dan pengamatan di lapangan. Pengaruh antar peubah, diuji menggunakan SEM (Structural Equation Modelling). Hasil penelitian menemukan bahwa tingkat keberdayaan transmigran dalam berusahatani dalam kategori rendah. Faktor yang berpengaruh terhadap keberdayaan adalah ketersediaan faktor pendukung, dukungan lingkungan sosial budaya, kegiatan penyuluhan, pelatihan calon transmigran, dan karakteristik individu transmigran.
\end{abstract}

Kata kunci: transmigran, keberdayaan, berusahatani, transmigrasi, kesejahteraan

\section{Pendahuluan}

Indonesia merupakan negara kepulauan terbesar di dunia, namun memiliki persebaran penduduk yang sangat timpang. Berdasarkan data Badan Pusat Statistik (BPS) tahun 2013, sekitar 57,49\% dari jumlah penduduk Indonesia tinggal di Pulau Jawa dan Madura yang luasnya hanya $6,96 \%$ dari luas daratan Indonesia. Sementara Kalimantan, pulau terluas di Indonesia (27,22\% dari luas daratan Indonesia), hanya dihuni oleh sekitar 5,8\% dari jumlah penduduk Indonesia. Papua, yang luasnya 22,83\% dari luas daratan Indonesia, dihuni oleh kurang dua persen dari total penduduk Indonesia.

Sekalipun penduduk merupakan modal awal pembangunan dan penggerak perekonomian yang potensial; namun terkonsentrasinya penduduk di suatu wilayah, seperti di Pulau Jawa, memicu berbagai persoalan. Penelitian Malamassam dan Surtiari (2011)

\footnotetext{
${ }^{1}$ Korespondensi penulis

E-mail: malta7875@yahoo.com
} 
menyebutkan bahwa kepadatan penduduk yang tinggi di suatu daerah mengakibatkan pemanfaatan sumber daya alam yang semakin besar dan pemanfaatan yang berlebihaan dapat memicu penurunan kualitas lingkungan. Noveria (2011) menyebutkan bahwa jumlah penduduk yang besar membutuhkan tuntutan kebutuhan akan berbagai layanan sosial dan ekonomi. Semakin banyak jumlah penduduk, semakin banyak pula diperlukan sarana prasarana pendidikan, kesehatan, berbagai layanan ekonomi seperti pasar, dan kebutuhan akan kesempatan kerja. Daya dukung yang terbatas akan menjadi ancaman terhadap pemenuhan hak-hak sosial ekonomi. Kesempatan kerja yang tidak memadai, menyebabkan banyak terjadi pengangguran yang akan memperburuk kondisi kemiskinan dan pada gilirannya dapat menimbulkan dampak buruk bagi lingkungan sosial.

Data BPS (2017) membuktikan bahwa masalah ketimpangan penyebaran penduduk diikuti dengan masalah lain seperti penggangguran. Jumlah pengangguran di Indonesia pada tahun 2017 mencapai 7,01 juta orang atau $5,33 \%$ dari total angkatan kerja di Indonesia. Sebanyak 60,2\% (4,2 juta orang) dari jumlah pengangguran tersebut, berada di Pulau Jawa. Transmigrasi merupakan salah satu alternatif yang penting dalam mengatasi berbagai masalah di bidang kependudukan. Melalui transmigrasi tidak saja memeratakan jumlah penduduk tetapi diharapkan juga mendistribusikan Sumber Daya Manusia (SDM) produktif untuk menggali setiap potensi yang ada dalam rangka meningkatkan kesejahteraan penduduk yang ditransmigrasikan dan seluruh penduduk di daerah transmigrasi serta wilayah sekitarnya. Romdiati dan Noveria (2002) menyebutkan bahwa bagi daerah yang masih jarang penduduk, migrasi masuk dapat berdampak positif terhadap perekonomian dan pembangunan. Masuknya penduduk usia kerja, maka akan menambah jumlah tenaga kerja yang dapat memanfaatkan potensi alam yang dimiliki daerah tersebut. Para pendatang juga dapat berperan dalam menggerakkan ekonomi, antara lain melalui keterlibatannya di sektor perdagangan.

Undang-Undang (UU) nomor 29 Tahun 2009 tentang Ketransmigrasian, menyatakan bahwa pembangunan transmigrasi merupakan suatu upaya percepatan pembangunan kota-kota kecil terutama di luar Pulau Jawa, untuk meningkatkan perannya sebagai motor penggerak pembangunan daerah, untuk meningkatkan daya saing daerah yang masih rendah sebagai akibat antara lain lebarnya kesenjangan antar wilayah. Hal tersebut disebutkan, terutama antara kawasan perdesaan-perkotaan, Jawa-luar Jawa, dan antara kawasan Timur-Barat, serta rendahnya keterkaitan antara pusat pertumbuhan dengan daerah belakang (hinterland), termasuk antara desa dan kota.

Seiring dengan era otonomi daerah, pelaksanaan program transmigrasi juga memasuki era baru dengan paradigma yang baru. Transmigrasi tidak lagi semata program pemindahan penduduk, melainkan upaya untuk pengembangan wilayah dan pembentukan pusatpusat pertumbuhan, serta memenuhi kebutuhan sumber daya manusia yang diperlukan untuk mengembangkan potensi sumber daya yang tersedia (Manuwiyoto, 2004; Saksono, 2011). Sasaran penyelenggaraan pembangunan transmigrasi adalah meningkatkan kemampuan dan produktivitasmasyarakattransmigrasi, membangun kemandirian dan mewujudkan integrasi di permukiman transmigrasi sehingga ekonomi dan sosial budaya mampu tumbuh dan berkembang secara berkelanjutan. Tujuan program transmigrasi sebagaimana disebutkan di atas merupakan target ideal yang diharapkan dapat terwujud, namun kondisi para transmigran di kawasan transmigrasi harus menjadi perhatian utama dalam rangka mewujudkan tujuantujuan dimaksud.

Kenyataan yang ada di kawasan transmigrasi, bahwa transmigran pada umumnya berasal dari masyarakat "lapisan bawah" yang berpendidikan rendah dan kurang mampu secara ekonomi (Manuwiyoto, 2004; Saleh, 2005; Kemenakertrans, 2013). Transmigran adalah para pendatang yang berasal dari berbagai daerah dengan latar belakang sosial dan budaya yang berbeda-beda. Para transmigran harus memulai dan menjalani "kehidupan baru" di daerah yang sama sekali baru. Keadaan yang sangat berbeda dengan kondisi daerah asal, kondisi alam serta lingkungan sosial, ekonomi, dan budaya yang baru. Hal ini harus dijalani dan dihadapi di tengah tantangan hidup, tuntutan nafkah yang semakin meningkat, dan persaingan usaha yang makin kompetitif; walaupun ada bantuan jaminan hidup dan sarana produksi pada awal penempatan, namun tidak selalu mudah untuk menjalankan dan mengembangkan kegiatan usaha.

Mengingat keadaan di atas, diperlukan pengembangan 
sumber daya manusia transmigran yang berdaya. Keberdayaan yang tinggi terindikasi dari kemampuan dalam perencanaan usaha, pengelolaan proses produksi, pengelolaan permodalan, dan pengelolaan pemasaran.

Program pendampingan masyarakat transmigrasi merupakan kegiatan yang dilaksanakan pasca penempatan dengan tujuan untuk memantapkan kehidupan ekonomi, sosial, dan budaya transmigran di permukiman yang telah dibangun. Pengembangan masyarakat dan kawasan transmigrasi seharusnya dirancang dalam kerangka untuk menjadikan masyarakat transmigrasi berdaya dalam menjalankan kegiatan usahanya, sehingga tercapai kesejahteraan.

Kebijakan transmigrasi masih mengarahkan transmigran untuk bekerja di sektor pertanian dengan usaha produksi berbasis tanah, serta belum banyak upaya untuk diversifikasi pola usaha transmigran. Pola usaha dan permukiman transmigrasi hampir seluruhnya dibangun dengan orientasi pengembangan pertanian (Manuwiyoto, 2008; Kemenakertrans, 2013). Implikasi dari kebijakan tersebut, sehingga pada umumnya yang ditransmigrasikan adalah para petani atau keluarga/ masyarakat yang siap untuk menjalankan usaha di sektor pertanian. Pengembangan masyarakat transmigrasi secara umum berarti pengembangan masyarakat petani dalam berusahatani.

Pemberdayaan transmigran dalam berusahatani adalah sasaran yang seharusnya menjadi tujuan pengembangan masyarakat dan kawasan transmigrasi. Tujuan penelitian ini adalah menganalisis tingkat keberdayaan transmigran dalam berusahatani dan mengkaji faktor-faktor yang berpengaruh terhadap tingkat keberdayaan tersebut.

\section{Metode Penelitian}

Jenis penelitian yang digunakan adalah penelitian eksplanatori yaitu untuk menelaah hubungan antara peubah-peubah penelitian dan menguji hipotesis yang telah dirumuskan sebelumnya. Penelitian dilakukan bulan Mei 2016 sampai Januari 2017. Lokasi penelitian di Kabupaten Banyuasin dan Ogan Ilir Provinsi Sumatera Selatan, dengan pertimbangan merupakan kawasan dengan jumlah transmigran yang besar di Provinsi Sumatera Selatan. Jumlah populasi adalah 3.537 rumah tangga transmigran. Besarnya sampel dalam penelitian ini ditentukan dengan menggunakan rumus Slovin. Jumlah sampel sebanyak 359 responden. Penarikan sampel secara acak berstrata (stratified random sampling), dengan strata: Permukiman Transmigrasi (PT), tahun penempatan, jenis transmigrasi, dan asal transmigrasi (lokal dan luar provinsi).

Pengumpulan data dilakukan untuk mendapatkan data primer dan data sekunder. Data primer diperoleh melalui wawancara terstruktur, wawancara mendalam, dan pengamatan di lapangan. Pengaruh antar peubah diuji menggunakan SEM (Structural Equation Modelling).

\section{Hasil dan Pembahasan}

Setelah enam sampai 15 tahun di lokasi transmigrasi ternyata tingkat keberdayaan transmigran pada saat ini tergolong rendah dalam aspek-aspek: perencanaan usaha, pengelolaan produksi, pengelolaan modal dan pengelolaan pemasaran. Persentase tiap-tiap kategori disajikan pada Tabel 1.

\section{Keberdayaan dalam Perencanaan Usaha}

Tingkat keberdayaan transmigran dalam merencanakan usaha termasuk dalam kategori rendah. Rendahnya keberdayaan dalam melakukan perencanaan usaha, terindikasidarikurangnyatransmigrandalammerencanakan aspek-aspek produksi seperti: merencanakan input produksi, modal, dan pemasaran.

Menurut transmigran kegiatan usahatani yang dilakukan hanya berdasarkan pengalaman dan kebiasaan saja yang tidak dituangkan dalam bentuk tertulis, transmigran tidak mempunyai catatan usaha tani (farm recording); transmigran hanya mengingat-ingat anggaran arus uang tunai (cash flow) yang telah dilakukan. Transmigran menyebutkan belum mempunyai kebiasaan untuk membuat perencanaan usahatani secara tertulis. Kebiasaan yang terjadi selama ini, adalah hanya mengikuti kegiatankegiatan yang sudah dilakukan masa-masa sebelumnya sehingga unsur perencanaan diabaikan.

Padahal dengan perencanaan usaha, kegiatan berbagai pembaharuan-pembaharuan dalam usahatani dapat dilakukan. Perencanaan merupakan langkah awal yang penting bagi keberhasilan suatu kegiatan. Perencanaan yang baik dan sistematis dapat memberikan arah 
Tabel 1. Sebaran Tingkat Keberdayaan Transmigran di Kabupaten Banyuasin dan Ogan Ilir

\begin{tabular}{|c|c|c|c|c|c|}
\hline \multirow{3}{*}{ No } & \multirow{3}{*}{ Sub Peubah Tingkat Keberdayaan } & \multirow{3}{*}{ Kategori } & \multicolumn{2}{|c|}{ Kabupaten } & \multirow{2}{*}{$\begin{array}{c}\text { Total } \\
(n=359)\end{array}$} \\
\hline & & & $\begin{array}{c}\text { Banyuasin } \\
(\mathrm{n}=284)\end{array}$ & $\begin{array}{c}\text { Ogan Ilir } \\
(n=75)\end{array}$ & \\
\hline & & & $(\%)$ & $(\%)$ & $(\%)$ \\
\hline \multirow[t]{4}{*}{1} & Perencanaan usahatani & Rendah & 90,1 & 81,3 & 88,3 \\
\hline & \multirow{3}{*}{ Rataan skor: 36,3} & Sedang & 9,9 & 18,7 & 11,7 \\
\hline & & Tinggi & 0,0 & 0,0 & 0,0 \\
\hline & & Jumlah & 100,0 & 100,0 & 100,0 \\
\hline \multirow[t]{4}{*}{2} & Pengelolaan produksi & Rendah & 73,9 & 62,7 & 71,6 \\
\hline & \multirow{3}{*}{ Rataan skor: 41,8} & Sedang & 26,1 & 37,3 & 28,4 \\
\hline & & Tinggi & 0,0 & 0,0 & 0,0 \\
\hline & & Jumlah & 100,0 & 100,0 & 100,0 \\
\hline \multirow[t]{4}{*}{3} & Pengelolaan modal & Rendah & 100,0 & 100,0 & 100,0 \\
\hline & \multirow{3}{*}{ Rataan skor: 22,9} & Tinggi & 0,0 & 0,0 & 0,0 \\
\hline & & Tinggi & 0,0 & 0,0 & 0,0 \\
\hline & & Jumlah & 100,0 & 100,0 & 100,0 \\
\hline \multirow[t]{4}{*}{4} & Pengelolaan pemasaran & Rendah & 93,7 & 88,0 & 92,5 \\
\hline & \multirow{3}{*}{ Rataan skor: 23,3} & Sedang & 6,3 & 12,0 & 7,5 \\
\hline & & Tinggi & 0,0 & 0,0 & 0,0 \\
\hline & & Jumlah & 100,0 & 100,0 & 100,0 \\
\hline
\end{tabular}

Keterangan: Nilai rataan skor: Rendah $=0-50$, Sedang $=51-75$, Tinggi $=76-100$

dan menjadi pedoman bagi berlangsungnya suatu kegiatan. Perencanaan usahatani sangat terkait dengan kemampuan dalam mengidentifikasi kebutuhan yang harus dipenuhi, menganalisis masalah dan kebutuhan, serta merencanakan pemanfaatan potensi dan berbagai sumber daya yang ada.

Faktor terbatasnya akses informasi, ikut berkontribusi sebagai penyebab rendahnya keterampilan transmigran dalam merencanakan usahatani. Transmigran kurang mempunyai akses informasi tentang input produksi, modal, dan pasar. Perencanaan usahatani yang akurat membutuhkan data yang cakupannya luas dan akurat. Informasi yang hanya menggambarkan kondisi setempat untuk menyusun perencanaan usahatani, maka tidak memadai. Kaye (1997) menyebutkan bahwa seseorang akan mampu mengenali inti permasalahan yang sedang dihadapi dan mampu merumuskan perencanaan yang baik jika diperoleh informasi lebih banyak. Sangat dibutuhkan sumber daya, upaya ekstra, serta akses dari setiap orang terhadap sumber informasi.

\section{Keberdayaan dalam Pengelolaan Produksi}

Tingkat keberdayaan transmigran dalam mengelola produksi termasuk dalam kategori rendah. Hal ini terindikasi dari kurang optimalnya transmigran dalam melakukan pengelolaan usahatani. Lahan usahatani transmigran adalah lahan rawa, sehingga idealnya dibuat guludan pada permukaan tanah. Kebanyakan transmigran tidak membuat guludan. Menurut Rosyid dan Sahuri (2014) dan Noor (2007), guludan berfungsi untuk menjauhkan permukaan air tanah dengan permukaan tanah agar dapat diperoleh perkembangan akar yang baik. Penanaman tanaman pada guludan memiliki pengaruh yang positif terhadap pertumbuhan. Pada lahan rawa lebak, untuk pengelolaan air sudah ada saluran atau parit di sekeliling lahan, namun transmigran tidak membuat saluran cacing atau kemalir di petakan lahan. Menurut Haerani dan Nursyamsi (2012) dan Noor (2007), saluran air atau kemalir di petakan lahan diperlukan untuk pengelolaan air di lahan rawa lebak. 
Pemberian amelioran diperlukan untuk menaikkan $\mathrm{pH}$ lahan dan penyediaan unsur hara yang dibutuhkan tanaman. Kapur sangat efektif untuk meningkatkan pH lahan (Sudana, 2005). Pada masa awal pembukaan lahan, telah dilakukan pemberian kapur pada lahan, namun untuk selanjutnya kebanyakan transmigran tidak melakukan pemberian kapur (semestinya minimal sekali setahun) sebagaimana teknologi anjuran, alasan transmigran karena keterbatasan modal.

Tanaman utama yang ditanam transmigran adalah karet dan kelapa sawit. Ketika tanaman sudah menghasilkan, umumnya transmigran jarang memberikan pupuk untuk tanaman. Alasan yang dikemukakan adalah juga karena terbatasnya kemampuan modal finansial untuk menjangkau harga pengadaan sarana usaha yang terus meningkat dari waktu ke waktu di tingkat petani/ transmigran. Menurut Tim Penebar Swadaya (2008) dan Fauzi et al., (2012), pemupukan pada karet tetap harus diberikan dua kali setiap tahun, dan tiga kali setahun untuk kelapa sawit. Pemupukan berpengaruh terhadap pertumbuhan dan produksi tanaman, karena dengan pemupukan akan meningkatkan kesuburan tanah, meningkatkan daya tahan tanaman terhadap serangan penyakit dan pengaruh iklim yang merugikan. Sebagian besar(63\%) transmigran sudah memerhatikan jarak tanaman sesuai teknologi anjuran, yaitu: $7 \times 3$ meter untuk karet dan 9x9 meter untuk kelapa sawit. Sebagian yang lain, menanam karet dengan jarak tanam $5 \times 3$ meter dan $8 \times 9$ meter untuk kelapa sawit, transmigran beralasan supaya lebih banyak populasi tanaman per satuan luas lahan. Padahal tanaman yang terlalu rapat menyebabkan persaingan penyerapan unsur hara yang akan memengaruhi pertumbuhan dan produksi hasil (Tim Penebar Sawadaya 2008).

Umumnya transmigran melakukan penyulaman terhadap tanaman yang mati sebelum masa tiga tahun. Transmigran menyadari pentingnya penyulaman untuk memastikan seluruh hamparan lahan dapat ditanami tanaman, supaya dapat dicapai produksi yang lebih banyak.

Penyakit yang banyak menyerang karet di lokasi transmigrasi adalah akar putih dan gugur daun. Kebanyakan transmigran membiarkan saja penyakit tersebut dan tidak diobati, alasan yang dikemukakan bahwa tidak mengetahui obatnya dan tidak punya dana yang cukup untuk pembelian obat untuk tanaman.
Transmigran melakukan pemangkasan pelepah kelapa sawit setiap enam atau delapan bulan sekali. Pengetahuan ini didapat pada saat pelatihan dan informasi dari sesama transmigran. Namun transmigran tidak melakukan penyerbukan buatan untuk mendapatkan tandan dengan ukuran dan jumlah buah yang optimal. Transmigran hanya mengandalkan penyerbukan alami. Padahal penyerbukan alami dinilai kurang menguntungkan, karena jumlah buah yang dihasilkan lebih sedikit (Fauzi et al., 2012). Transmigranmengutarakan bahwa tidak mengetahui cara penyerbukan buatan tersebut.

Umumnya transmigran terampil dalam menentukan waktu panen yang tepat pada tanaman kelapa sawit dengan melihat ciri tanaman, yaitu: buah berwarna merahjingga atau sudah adabuah yangjatuh dari tangkai tandan. Namun transmigran kurang terampil dalam menentukan waktu panen yang tepat pada tanaman karet. Desakan kebutuhan keuangan, menjadikan transmigran memanen karet walaupun belum matang sadap. Menurut Tim Penebar Swadaya (2008), karet yang memiliki tingkat pertumbuhan normal siap disadap pada umur lima tahun dan lilit batang $45 \mathrm{~cm}$ dari batas pertautan okulasi atau permukaan tanah. Penyadapan yang dilakukan sebelum matang sadap, akan menghasilkan lateks yang kurang mantap dan mudah menggumpal. Selain itu, juga mengurangi produksi dan akan memengaruhi pertumbuhan pohon karet.

Transmigran menggunakan cuka para (asam sulfat), pupuk TSP, dan tawas sebagai bahan penggumpal karet. Penggunaan bahan ini merusak mutu karet. Alasan transmigran menggunakan bahan-bahan tersebut, karena harga yang lebih murah, mudah didapat, dan mudah pemakaiannya. Bahan yang dianjurkan untuk membekukan karet adalah dengan asam format/asam semut. Bahkan, Pusat Penelitian Karet Sembawa sudah mengembangkan larutan Deorub, sebagai bahan penggumpal karet yang ramah lingkungan (pencegah bau busuk karet) dan harganya relatif murah; namun informasi tentang inovasi tersebut belum diketahui oleh mayoritas transmigran. Perlu penanganan pascapanen yang baik dan tepat agar kualitas lateks yang dihasilkan memenuhi permintaan pasar.

Menurut Fauzi et al., (2012) tandan buah segar (TBS) kelapa sawit yang baru dipanen seharusnya segera 
diangkut ke pabrik dan tidak boleh melebihi delapan jam setelah panen. Praktik yang terjadi di lokasi transmigrasi, bahwa TBS ditumpuk lebih dari 24 jam untuk menunggu tengkulak yang membeli dan membawanya ke pabrik. Kondisi ini menurunkan mutu TBS kelapa sawit. Perlu penanganan pascapanen yang baik dan tepat agar kualitas buah sawit harus tetap segar sampai datang di pabrik, karena bila tidak segar akan berpengaruh terhadap kualitas hasil olahan $(\mathrm{CPO} /$ Crude Palm Oil).

Salah satu kemampuan utama yang harus dimiliki oleh petani adalah kemampuan dalam mengelola produksi. Keberdayaan transmigran dalam mengelola produksi didasari atas kemampuan dalam teknik usahatani, kemampuan memanfaatkan potensi sumber daya alam, kemampuan dalam mengambil keputusan usahatani, adanya sense of agribusiness, keterampilan agribisnis yang dimiliki, dan adanya orientasi pada pertanian masa depan. Dalam banyak aspek, transmigran di lokasi penelitian masih banyak menghadapi hambatan dan keterbatasan-keterbatasan, baik dalam modal, akses informasi, serta kemampuan dalam hal teknis dan manajemen usaha.

\section{Keberdayaan dalam Pengelolaan Modal}

Tingkat keberdayaan transmigran dalam mengelola modal termasuk dalam kategori rendah. Hal tersebut terindikasi dari kurang mampunya transmigran dalam mendapatkan informasi akses modal serta kurang mengakses sumbersumber modal, serta rendahnya kemampuan dalam pembuatan pembukuan keuangan.

Keterampilan transmigran dalam pembuatan pembukuan keuangan memperlihatkan kategori lebih rendah dibandingkan aspek kemampuan yang lain. Rendahnya pengetahuan transmigran tentang pengelolaan pembukuan/administrasi menyebabkan keterampilan dalam pembuatan pembukuan keuangan juga rendah. Para transmigran mengakui jarang membuat pembukuan usahatani, biasanya hanya mengandalkan ingatan. Seperti setelah berbelanja atau membeli saprodi, tidak pernah mencatat ulang atau menyimpan bukti pembayaran saprodi.

Melakukan pembukuan/pencatatan keuangan, berarti mengarsipkan informasi mengenai catatan transaksi keuangan sehingga dapat menjadi dasar dalam membuat keputusan usaha. Menurut Astuti (2012), catatan keuangan memberi gambaran perkembangan keuangan usaha dari waktu ke waktu dan pengambilan keputusan usaha dapat dilakukan lebih baik, karena berdasarkan data-data yang akurat serta dapat direncanakan secara baik pola usaha yang akan dilakukan.

\section{Keberdayaan dalam Pengelolaan Pemasaran}

Tingkat keberdayaan transmigran dalam mengelola pemasaran termasuk dalam kategori rendah. Hal tersebut terindikasi dari rendahnya kemampuan mendapatkan daerah pemasaran baru dan menganalisis permintaan konsumen.

Kemampuan transmigran yang rendah dalam mendapatkan daerah pemasaran baru, terkait dengan rendahnya akses informasi transmigran tentang pembeli ataukonsumen baru. Pada sisi lain, mendapatkan pembeli baru akan memperkuat posisi tawar transmigran sebagai pihak penghasil komoditas. Menurut Govindasamy et al., (2002), informasi tentang preferensi dan harapan konsumen memungkinkan petani untuk merencanakan produksi, penetapan harga, dan strategi pemasaran secara lebih efisien. Soekartawi (2005) menambahkan bahwa agar produk-produk mendapatkan harga yang layak, produsen produk harus memanfaatkan semua peluang-peluang pasar yang ada.

\section{Faktor-faktor yang Memengaruhi Keberdayaan Transmigran}

Faktor-faktor yang berpengaruh nyata terhadap tingkat keberdayaan transmigran dalam berusahatani adalah peubah: karakteristik individu transmigran (X1), pelatihan calon transmigran (X2), kegiatan penyuluhan (X3), dukungan lingkungan sosial budaya (X4), dan faktor pendukung (X5) (Gambar 1). Faktor-faktor tersebut memberikan pengaruh yang signifikan dalam mengembangkan keberdayaan transmigran dalam berusahatani pada aspek: perencanaan usaha, pengelolaan produksi, pengelolaan modal, dan pengelolaan pemasaran.

Secara simultan pengaruh peubah-peubah tersebut di atas terhadap keberdayaan transmigran dalam berusahatani adalah sebesar 0,72. Hal ini mempunyai makna bahwa karakteristik individu transmigran, pelatihan calon transmigran, kegiatan penyuluhan, dukungan 
lingkungan sosial budaya, dan faktor pendukung secara bersama-sama memengaruhi keberdayaan transmigran sebesar $72 \%$, sedangkan sisanya dijelaskan oleh peubah lain.

\section{PengaruhFaktor Pendukungterhadap Keberdayaan Transmigran dalam Berusahatani}

Pengaruhfaktorpendukungterhadaptingkatkeberdayaan transmigran dalam berusahatani direfleksikan oleh indikator-indikator, yaitu: ketersediaan sarana usaha, akses informasi, ketersediaan modal usaha, ketersediaan transportasi, kemudahan akses pasar, dan kelayakan lahan.

Tabel 2. Koefisien Faktor-Faktor yang Memengaruhi Keberdayaan Transmigran di Kabupaten Banyuasin dan Ogan Ilir

\begin{tabular}{|c|c|c|c|c|c|}
\hline No & $\begin{array}{c}\text { Peubah } \\
\text { Bebas }\end{array}$ & $\begin{array}{l}\text { Peubah } \\
\text { Terikat }\end{array}$ & $\begin{array}{l}\text { Koefisien } \\
\text { Jalur }\end{array}$ & $\begin{array}{l}\text { Nilai t } \\
\text { Hitung }\end{array}$ & $\mathbf{R}^{2}$ \\
\hline 1 & $\begin{array}{l}\text { Karak- } \\
\text { teris-tik } \\
\text { individu } \\
\text { transmi- } \\
\text { gran }\end{array}$ & $\begin{array}{l}\text { Keberdayaan } \\
\text { transmigran }\end{array}$ & 0,12 & 2,44 & \\
\hline 2 & $\begin{array}{l}\text { Pelatihan } \\
\text { calon } \\
\text { transmi- } \\
\text { gran }\end{array}$ & & 0,14 & 2,08 & \\
\hline 3 & $\begin{array}{l}\text { Kegiatan } \\
\text { penyulu- } \\
\text { han }\end{array}$ & & 0,32 & 5,49 & 0,72 \\
\hline 4 & $\begin{array}{l}\text { Dukun- } \\
\text { gan } \\
\text { lingkun- } \\
\text { gan sosial } \\
\text { budaya }\end{array}$ & & 0,19 & 3,37 & \\
\hline 5 & $\begin{array}{l}\text { Faktor } \\
\text { pen- } \\
\text { dukung }\end{array}$ & & 0,93 & 11,63 & \\
\hline
\end{tabular}

Indikator ketersediaan sarana usaha merupakan indikator yang paling kuat $(\lambda=0,89)$ merefleksikan peubah faktor pendukung, diikuti indikator akses informasi $(\lambda=0,58)$ dan indikator ketersediaan modal usaha $(\lambda=0,54)$. Indikator lainnya yang turut merefleksikan peubah faktor pendukung adalah indikator ketersediaan transportasi $(\lambda=0,55)$, dan indikator kemudahan akses pasar $(\lambda=0,52)$, serta indikator kelayakan lahan $(\lambda=0,42)$.
Keberdayaan transmigran dalam berusahatani berada pada kategori yang rendah pada semua aspek. Rendahnya keberdayaan transmigran dipengaruhi oleh rendahnya faktor pendukung. Keterbatasan transmigran dalam akses: sarana usaha, informasi, modal, transportasi, pasar, serta kelayakan lahan yang rendah, menyebabkan kemampuan transmigran rendah dalam melakukan kegiatan usahatani, yaitu dalam: merencanakan usaha, mengelola produksi, mengelola pasar, dan mengelola modal.

Gambaran hubungan antara faktor pendukung dengan tingkat keberdayaan transmigran dalamberusahatani adalah sebagai berikut, rendahnya akses informasi menyebabkan transmigran terkendala dalam merencanakan usaha input produksi, modal, dan pemasaran. Keterbatasan akses informasi teknologi, menyebabkan transmigran tidak pernah menggunakan musuh alami dalam mengendalikan hama tanaman. Terbatasnya akses sarana usaha, menjadikan penggunaan bibit unggul rendah sehingga kuantitas dan kualitas produksi rendah, yang berakibat harga produk tidak optimal.

Rendahnya akses modal, menyebabkan keterbatasan transmigran dalam penggunaan pupuk dan obat-obatan tanaman, karena kekurangan dana untuk membeli sarana produksi. Penggunaan pupuk yang tidak sesuai takaran serta panen sebelum waktunya, memengaruhi mutu produk dan berefek pada rendahnya kemampuan menganalisis permintaan konsumen.

Rendahnya akses transportasi, menyebabkan harga sarana usaha mahal dan berakibat pada rendahnya pengendalian penyakit tanaman. Keterbatasan akses transportasi juga menyebabkan transmigran kesulitan dalam memasarkan produk, karena kendaraan tidak leluasa untuk membawa hasil panen dari lokasi transmigrasi. Mosher (1987) menyebutkan bahwa prasarana jalan merupakan syarat pokok dalam pembangunan pertanian. Yamin (2017) mengutarakan bahwa jalan merupakan salah satu infrastruktur yang sangat diperlukan untuk menjamin aksesibilitas dan mobilitas barang dan jasa.

Rendahnya kelayakan lahan berakibat pada rendahnya mutu dan jumlah produksi, sehingga transmigran kesulitan untuk menjual produk dengan harga yang paling menguntungkan. Belum optimalnya akses pasar, berakibat rendahnya kemampuan dalam pemupukan modal usaha karena keuntungan yang diperoleh belum 


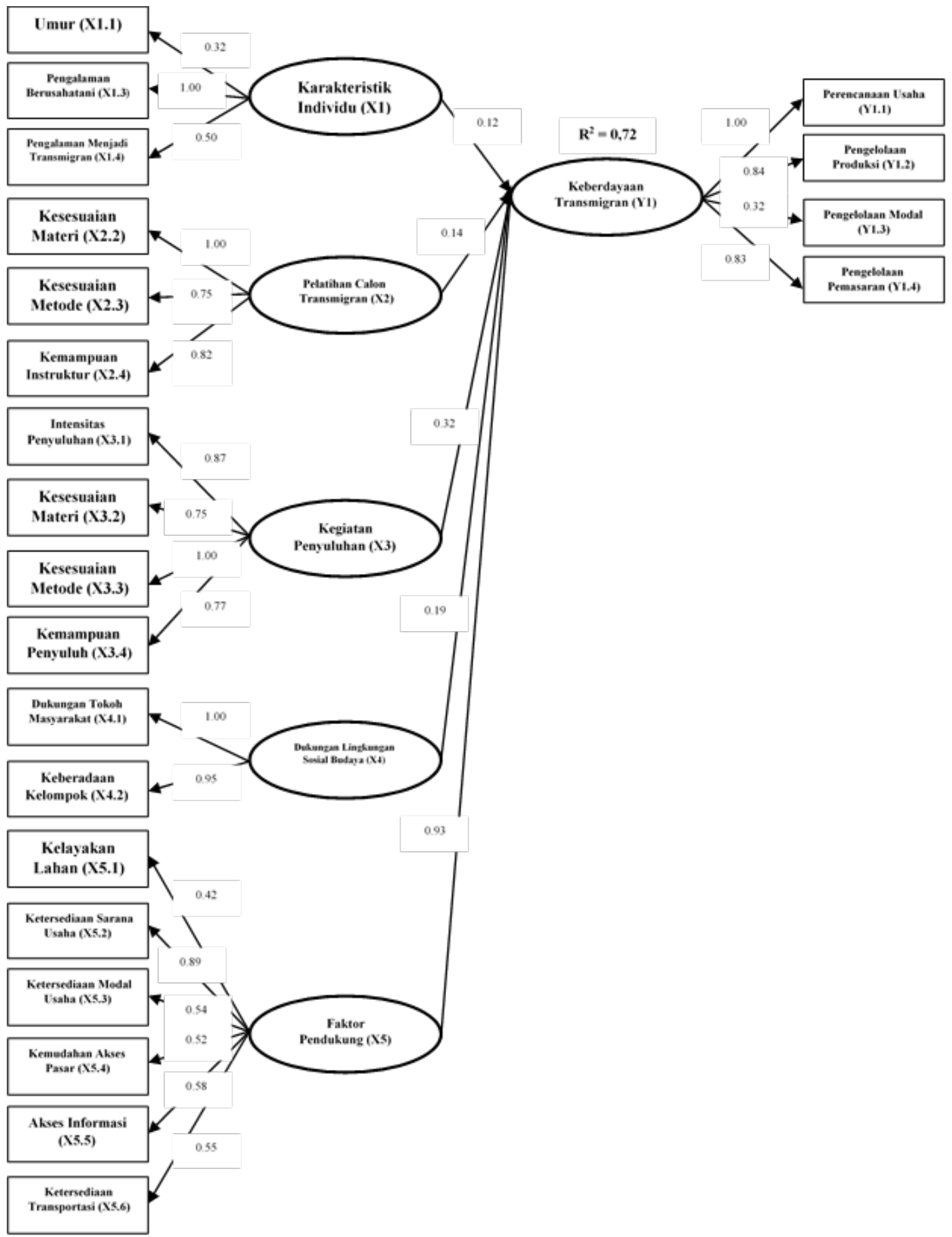

Gambar 1. Faktor-Faktor yang Memengaruhi Keberdayaan Transmigran dalam Berusahatani

optimal. Temuan ini sejalan dengan hasil penelitian Helmida (2004), bahwa faktor lahan, transportasi, dan pasar, berpengaruh terdahap optimalisasi keberhasilan usahatani transmigran.

Pengaruh positifnyata faktor pendukung terhadap tingkat keberdayaan transmigran dalam berusahatani, berarti bahwa jika ketersediaan faktor pendukung dioptimalkan maka keberdayaan transmigran dalam berusahatani akan meningkat. Upaya mengembangkan keberdayaan transmigran dalam berusahatani diperlukan peningkatan dalam hal: ketersediaan sarana usaha, akses informasi, ketersediaan modal usaha, ketersediaan transportasi, kemudahan akses pasar, dan kelayakan lahan.

\section{Pengaruh Kegiatan Penyuluhan terhadap Keberdayaan Transmigran dalam Berusahatani}

Pengaruh kegiatan penyuluhan terhadap tingkat keberdayaan transmigran dalam berusahatani direfleksikan 
oleh indikator-indikator: kesesuaian metode, intensitas penyuluhan, kesesuaian materi, dan kemampuan penyuluh. Indikator kesesuaian metode merupakan indikator yang paling kuat $(\lambda=1,00)$ merefleksikan peubah kegiatan penyuluhan, diikuti indikator intensitas penyuluhan $(\lambda=$ 0,89 ). Indikator berikutnya yaitu kemampuan penyuluh $(\lambda=0,77)$ dan indikator kesesuaian materi $(\lambda=0,75)$.

Keberdayaan transmigran dalam berusahatani berada pada kategori yang rendah. Rendahnya keberdayaan transmigran dipengaruhi oleh rendahnya kegiatan penyuluhan di lokasi transmigrasi. Hal ini sejalan dengan temuan Tahitu (2013) dan Pan (2014), bahwa kegiatan penyuluhan berhubungan dengan kemampuan petani dalam berusahatani.

Implikasi dari keadaan ini adalah bahwa untuk mengembangkan keberdayaan transmigran dalam berusahatani diperlukan pengembangan kegiatan penyuluhan yang sesuai dengan kebutuhan dan masalah transmigran. Masyarakat transmigrasi memiliki berbagai tingkat pengetahuan, pengalaman, dan pola berpikir yang berbeda. Untuk menambah pengetahuan, pengalaman, serta mengubah sikap mental yang lebih bermanfaat bagi dirinya sangat diperlukan adanya kegiatan penyuluhan yang lebih intensif sesuai dengan permasalahan dan potensi yang dimilikinya. Amanah (2007) mengutarakan bahwa sebagai sebuah tindakan praktis, penyuluhan merupakan upaya-upaya yang dilakukan untuk mendorong terjadinya perubahan perilaku pada individu, kelompok, komunitas, ataupun masyarakat agar mereka tahu, mau, dan mampu menyelesaikan permasalahan yang dihadapi.

Kondisi yang ada, materi penyuluhan dirancang dalam suatu paket yang tidak berhubungan dengan kebutuhan nyata transmigran. Materi yang berkaitan dengan pemupukan modal usaha serta pengelolaan pemasaran masih sangat kurang disampaikan pada kegiatan penyuluhan di lokasi studi. Begitu juga materi tentang perencanaan usaha, sangat jarang didapatkan oleh transmigran. Penyuluh terkadang memberikan materi tentang pengelolaan usahatani; namun materi yang diberikan berkaitan dengan budi daya tanaman pangan dan hortikultura, sedangkan komoditas utama transmigran adalah tanaman perkebunan.

Metode penyuluhan di lokasi transmigrasi kurang mampu memberdayakan transmigran, karena proses penyuluhan berlangsung masih sebatas mentransfer ilmu kepada transmigran. Model komunikasi satu arah, penyuluh sebagai pemberi informasi dan transmigran sebagai penerima informasi. Transmigran kurang aktif terlibat dalam proses penyuluhan karena penyuluh terfokus pada pemberian sejumlah materi yang sudah ditargetkan. Keberhasilan penyuluhan dilihat dari banyaknya materi yang sudah disampaikan kepada transmigran. Intensitas kegiatan penyuluhan juga rendah serta tidak berkelanjutan, dan tidak didukung dengan kemampuan penyuluh yang sesuai. Semestinya proses penyuluhan berlangsung untuk menggali, menelusuri, dan menemukan ilmu dan teknologi yang dibutuhkan transmigran. Franz et al., (2010) menyebutkan bahwa penyuluh tidak hanya harus menjadi ahli dalam materi penyuluhan tertentu tetapi juga menjadi arsitek hubungan, proses pembelajaran, dan lingkungan yang secara langsung memenuhi kebutuhan petani untuk mengkatalisasi pembelajaran.

Uraian tersebut, menggambarkan bahwa kegiatan penyuluhan belum dilakukan secara tepat. Kegiatan penyuluhan yang ada belum sesuai dengan konsep yang seharusnya. Hal tersebut memberi efek kepada rendahnya keberdayaan transmigran dalam merencanakan usahatani, melakukan pengelolaan produksi, serta rendah dalam melakukan pengelolaan pasar dan modal. Slamet (2001) mengutarakan bahwa kegiatan penyuluhan merupakan proses pendidikan non formal secara berkelanjutan bagi petani, yang bertujuan meningkatkan pengetahuan, kemauan, dan kemampuannya sehingga petani mampu mengambil keputusan terbaik terhadap usahataninya. Penyuluhan bertujuan mengembangkan kemampuan petani agar berdampak pada pengembangan kualitas hidupnya.

Perubahan terus terjadi, misal kemajuan teknologi terus berkembang, tuntutan pasar atau konsumen terus meningkat termasuk beragamnya permasalahan usahatani di lahan rawa. Transmigran perlu mengetahui setiap perubahan tersebut agar mampu menghadapi berbagai perubahan yang terjadi. Peran penyuluh diperlukan bagi transmigran untuk menjembatani kondisi tersebut. Penyuluhan merupakan proses pembelajaran bagi transmigran. Kesertaan transmigran dalam penyuluhan perlu ditingkatkan dengan mengaktifkan terus kegiatan penyuluhan. Perlu dikembangkan penyuluhan secara terencana dan berkelanjutan, yang sesuai kebutuhan dan masalah 
yang dihadapi transmigran. Kegiatan penyuluhan yang sesuai dengan konsep penyuluhan yang memiliki tujuan, falsafah, maupun prinsip penyuluhan. Diperlukan penyuluh yang terdidik dan kompeten, dan keberadaannya berpihak kepada transmigran untuk mengembangkan keberdayaan transmigran dalam berusahatani.

\section{Pengaruh Dukungan Lingkungan Sosial Budaya terhadap Keberdayaan Transmigran dalam Berusahatani}

Pengaruh dukungan lingkungan sosial budaya terhadap tingkat keberdayaan transmigran dalam berusahatani direfleksikan oleh indikator dukungan tokoh masyarakat dan keberadaan kelompok. Indikator dukungan tokoh masyarakat merupakan indikator yang paling kuat $(\lambda=$ $1,00)$ merefleksikan peubah dukungan lingkungan sosial budaya dan diikuti indikator keberadaan $\operatorname{kelompok}(\lambda=$ $0,95)$.

Keberdayaan transmigran dalam berusahatani berada pada kategori yang rendah, pada semua aspek yaitu: perencanaan usaha, pengelolaan produksi, pengelolaan pemasaran, dan pengelolaan modal. Rendahnya keberdayaan transmigran dipengaruhi secara signifikan oleh rendahnya dukungan lingkungan sosial budaya di lokasi transmigrasi, yaitu rendahnya dukungan tokoh masyarakat dan keberadaan kelompok.

Pengaruh positif nyata dukungan lingkungan sosial budaya terhadap tingkat keberdayaan transmigran dalam berusahatani, berarti bahwa jika peran tokoh masyarakat dan kelompok tani kuat maka keberdayaan transmigran dalam berusahatani akan meningkat. Hal ini mengisyaratkan perlunya peningkatan peran tokoh masyarakat dan pengembangan kelompok tani.

Peningkatan peran tokoh masyarakat adalah dengan pelibatan dalam penerapan inovasi teknologi, serta membantu dalam menjembatani kerja sama dengan pihak terkait untuk akses teknologi/inovasi, sarana usaha, modal dan pasar. Lippitt et al., (1958) menyebutkan bahwa sangat penting menggerakkan tokoh masyarakat dalam memantapkan upayaupaya perubahan dan merancang tahapan-tahapan perubahan yang direncanakan. Ibrahim et al., (2014) menambahkan bahwa tokoh masyarakat memiliki potensi sebagai agen pembangunan yang mendukung terwujudnya kelompok yang dinamis, dan kelompok tani yang kuat akan dapat mendorong meningkatnya kerja sama antara individu kelompok dengan pihak luar.

Pengembangan kelompok tani adalah dengan mengaktifkan kelompok dengan kegiatan-kegiatan yang sesuai dengan kebutuhan transmigran. Kelompok tani tidak hanya sekedar memenuhi persyaratan untuk mendapatkan berbagai bantuan; namun perlu disertai perencanaan kegiatan bersama yang mendatangkan manfaat serta memberikan keuntungan bagi semua anggota. Kelompok tani pada dasarnya memiliki potensi berperan sebagai: wahana belajar mengajar, wahana untuk bekerja sama dengan pihak lain, serta sebagai unit produksi usahatani.

Kelompok tani merupakan sarana yang efektifdan efisien untuk meningkatkan pengetahuan dan keterampilan transmigran. Sebagaimana pendapat Abbas (1995) yang mengemukakan bahwa peranan kelompok tani adalah sebagai wahana belajar bagi petani agar terjadi interaksi, guna meningkatkan pengetahuan, sikap, dan keterampilan dalam berusahatani yang lebih baik serta berperilaku lebih mandiri untuk mencapai kehidupan yang lebih sejahtera. Lunandi (1993) mengatakan belajar adalah hasil kerja sama antara manusia. Dua atau lebih banyak manusia yang saling memberi dan menerima informasi akan belajar banyak karena pertukaran pengalaman, pertukaran pengetahuan, saling mengungkapkan dan menanggapi suatu masalah. Berdasarkan pengertian Lunandi tersebut, seseorang akan mudah belajar secara mandiri melalui kelompok sebagai media belajar dimana terjadi proses saling berbagi informasi.

Keterlibatan dalamkelompoktani menjadipenting sebagai sarana tempat berinteraksi, berkomunikasi, saling belajar, dan saling bertukar pengalaman antar transmigran, dan para transmigran akan memperoleh manfaat dari kegiatan tersebut dalammenunjang usaha pertaniannya. Kelompok tani juga dapat menjadi sarana belajar antara transmigran dengan penyuluh. Melalui kelompok tani, penyuluh dapat mengadakan penyuluhan usahatani. Melalui kelompok tani kegiatan penyuluhan dapat dilaksanakan secara lebih efektif dan efisien. Transmigran harus dimotivasi supaya aktif dalam kelompok tani serta mengaktifkan kelompok tani dengan berbagai kegiatan yang memberdayakan transmigran. 


\section{Pengaruh Pelatihan Calon Transmigran terhadap Keberdayaan dalam Berusahatani}

Pengaruh pelatihan calon transmigran di daerah asal, terhadap tingkat keberdayaan transmigran dalam berusahatani direfleksikan oleh indikatorindikator: kesesuaian materi, kemampuan instruktur, dan kesesuaian metode. Indikator kesesuaian materi merupakan indikator yang paling kuat $(\lambda=1,00)$ merefleksikan peubah pelatihan calon transmigran, diikuti indikator kemampuan instruktur $(\lambda=0,82)$, dan indikator kesesuaian metode $(\lambda=0,75)$.

Keberdayaan transmigran dalam berusahatani berada pada kategori yang rendah, pada semua aspek yaitu: perencanaan usaha, pengelolaan produksi, pengelolaan pemasaran, dan pengelolaan modal. Rendahnya keberdayaan transmigran dipengaruhi secara signifikan oleh rendahnya pelatihan calon transmigran di daerah asal.

Minimnya materi yang berhubungan dengan perencanaan usahatani, pengelolaan modal, dan pengelolaan pemasaran, ikut memengaruhi rendahnya keberdayaan transmigran dalam aspek-aspek tersebut. Materi tentang pengelolaan produksi cukup banyak diberikan dalam kegiatan pelatihan calon transmigran, namun substansi materinya yang berbeda dengan kondisi riil di lokasi transmigrasi. Materi yang diberikan pada saat pelatihan adalah tentang usahatani di lahan kering dan irigasi. Hal ini berbeda sama sekali dengan lahan untuk berusahatani yang digunakan di lokasi transmigrasi yaitu lahan rawa pasang surut dan rawa lebak, yang membutuhkan perlakuan yang berbeda dibandingkan lahan kering dan irigasi.

Terkait dengan metode pelatihan calon transmigran, lebih banyakmenggunakanceramah dansedikitnyademonstrasi dan praktik. Hal ini berpengaruh terhadap rendahnya pemahaman peserta terhadap materi yang disampaikan, dan pada akhirnya memengaruhi dalam penerapan pada kegiatan usahatani. Instruktur dalam menentukan metode pelatihan seharusnya mempertimbangkan tujuan pelatihan dan keadaan peserta pelatihan. Menurut van den Ban dan Hawkins (1999), metode untuk memengaruhi sangat beragam tergantung pada kepentingan dan tingkat keharmonisan yang memengaruhi dan yang dipengaruhi.

Pengaruhpositifnyatapelatihancalontransmigranterhadap tingkat keberdayaan transmigran dalam berusahatani, berarti bahwa jika pelatihan calon transmigran dilaksanakan secara optimal maka keberdayaan transmigran dalam berusahatani akan meningkat. Hal ini mengisyaratkan bahwa untuk mengembangkan keberdayaan transmigran dalam berusahatani diperlukan peningkatan kualitas pelaksanaan pelatihan calon transmigran. Pelatihan yang memerhatikan materi dan metode pelatihan yang sesuai dengan kebutuhan dan permasalahan transmigran, yang memerhatikan spesifik lokal; serta memastikan ketersediaan instruktur yang kompeten. Robbins (2001) mengatakan pelatihan adalah proses kegiatan pembelajaran antara pengalaman untuk mengembangkan pola perilaku seseorang dalam bidang pengetahuan, keterampilan, dan sikap untuk mencapai standar yang diharapkan. Penelitian Oberholtzer et al., menemukan bahwa petani sangat membutuhkan pelatihan yang sesuai dengan kebutuhan, dalam upaya pengembangan usahanya.

\section{Pengaruh Karakteristik Individu terhadap Keberdayaan Transmigran dalam Berusahatani}

Pengaruh karakteristik individu transmigran terhadap tingkat keberdayaan transmigran dalam berusahatani direfleksikan oleh indikator-indikator: pengalaman berusahatani, pengalaman menjadi transmigran, dan umur. Indikator pengalaman berusahatani merupakan indikator yang paling kuat $(\lambda=1,00)$ merefleksikan peubah karakteristik individu, diikuti indikator pengalaman menjadi transmigran $(\lambda=0,50)$. Indikator berikutnya yaitu umur $(\lambda=0,32)$.

Bertambahnya umur, maka transmigran akan semakin dewasa baik secara psikologis maupun secara sosiologis. Salkind (1989) mengutarakan bahwa secara umum, umur berkaitan dengan tingkat kematangan biologis dan psikologis seseorang dalam melakukan aktivitas. Suparno (2001) menyatakan umur berhubungan dengan berkembangnya kemampuan berpikir seseorang.

Kemampuan terbentuk melalui proses dan waktu yang panjang. Proses yang dialami selama bertahun-tahun akan membentuk kemampuan terhadap suatu subjek tertentu. Kedewasaan, seiring dengan bertambah usia maka transmigran akan semakin banyak mengalami proses dalam usahatani, yang dapat menjadikan lebih mampu/berdaya dalam melaksanakan aspek-aspek dalam kegiatan usahatani. 
Umur berbanding lurus dengan pengalaman berusahatani di lokasi transmigrasi. Pengalaman dalam berusahatani, yang dengan sendirinya ikut membentuk kemampuan tersendiri. Pengalaman berusahatani ikut membentuk perilaku dan kemampuan dalam mengelola usahatani, karena selama masa menjalankan usahatani akan mengalami proses belajar,termasukmemperolehpelajaran cara pengelolaan dan pengembangan usahatani. Semakin panjang tahun usaha semakin banyak pengalaman dan wawasan dalam berusahatani yang dapat mendukung terjadinya pengembangan keberdayaan transmigran. Havelock (1969) menyebutkan bahwa pengalaman akan memengaruhi kecenderungan seseorang untuk merasa memerlukan dan siap menerima pengetahuan baru.

Mengikut pandangan dunia pendidikan, pengalaman merupakan suatu akumulasi dari proses belajar yang dialami, yang dilakukan secara gradual atau pelan-pelan. Pengalaman tersebut diperoleh dari setiap peristiwa yang terjadi, baik gagal maupun berhasil. Melalui setiap kejadian tersebut, transmigran dapat mengambil pelajaran yang dimanfaatkan untuk berusahatani. Padmowihardjo (1994) menyatakan bahwa rangkaian setiap pengalaman yang berhasil merupakan suatu hasil proses belajar yang bersifat abstrak dan membentuk suatu peta kognitif. Hasil penelitian ini sejalan dengan temuan Tulak et al., bahwa pengalaman di bidang pertanian berpengaruh terhadap kemampuan dalam berusahatani.

Pengalaman menjadi transmigran adalah juga berbanding lurus dengan pengalaman dalam berusahatani. Walker (1973) menyebutkan bahwa pengalaman adalah hasil dari proses mengalami oleh seseorang yang memengaruhi terhadap informasi yang diterima. Mubyarto (2002) menyebutkan bahwa pengalaman dan kemampuan bertani yang telah dimiliki sejak lama, sehingga telah menjadi cara hidup (way of life) yang telah memberikan keuntungan dalam hidupnya. Pengalaman berusahatani selama menjadi transmigran merupakan proses pembelajaran yang sangat berharga untuk memperbaiki kelemahan dan meningkatkan keberhasilan dalam melaksanakan kegiatan usahatani berikutnya sehingga menjadi lebih baik. Penelitian Erfanizar et al., (2015) menemukan bahwa pengalaman petani berpengaruh signifikan terhadap kemajuan dalam berusahatani.

\section{Kesimpulan}

Transmigran di Kabupaten Banyuasin maupun Ogan
Ilir Provinsi Sumatera Selatan memiliki keberdayaan yang rendah dalam menjalankan kegiatan usahatani, baik dalam merencanakan usaha, mengelola produksi, mengelola modal, maupun dalam mengelola pemasaran. Faktor yang menyebabkan rendahnya keberdayaan transmigran dalam berusahatani adalah rendahnya ketersediaan faktor pendukung (sarana usaha, informasi, modal usaha, transportasi, pasar, dan kelayakan lahan), yang diikuti rendahnya dukungan lingkungan sosial budaya (dukungan tokoh masyarakat dan keberadaan kelompok). Faktor lain adalah rendahnya kegiatan penyuluhan di lokasi transmigrasi, rendahnya kualitas pelatihan bagi calon transmigran di daerah asal, serta tidak optimalnya kualitas karakteristik individu transmigran.

Upaya yang dapat dilakukan untuk mengembangkan keberdayaan transmigran dalam berusahatani adalah: (1) meningkatkan ketersediaan sumber daya pendukung, melalui: memfasilitasi transmigran melalui kelompok tani untuk bekerja sama dengan berbagai lembaga terkait, seperti: lembaga penyedia sarana produksi, lembaga inovasi, dan lembaga keuangan; (2) kebijakan dan keberpihakan pemerintah dalam membangun prasarana jalan dan jembatan di lokasi transmigrasi; (3) menumbuhkembangkan koperasi pada semua lokasi PT; (4) akses teknologi bagi transmigran guna menyiasati tingkat kesuburan lahan yang rendah, (5) keberpihakan pemerintah untuk penyelesaian sengketa lahan transmigran dengan perusahaan; (6) pelibatan tokoh masyarakat dalam penerapan inovasi teknologi, dan membantu dalam menjembatani kerja sama dengan pihak terkait untuk akses teknologi/inovasi, sarana usaha, modal dan pasar; serta (7) pengembangan kegiatan penyuluhan, melalui: peningkatan jumlah dan kompetensi penyuluh, meningkatkan frekuensi kegiatan penyuluhan yang memerhatikan materi pembelajaran sesuai dengan masalah yang dihadapi oleh transmigran dan metode penyuluhan yang partisipatif, komunikatif, dan dialogis.

\section{Daftar Pustaka}

Abbas S. 1995. 90 Tahun Penyuluhan Pertanian di Indonesia (1905-1995). Jakarta (ID): Deptan.

Amanah S. 2007. Makna Penyuluhan dan Transformasi Perilaku Manusia. Jurnal Penyuluhan 3 (1): 63-67. Astuti DSP. 2012. Perlunya Penerapan Sistem Akuntansi Pada Usaha Kecil Menengah. Jurnal 
Ekonomi dan Kewirausahaan 10 (2): 152-163.

Badan Pusat Statistik. 2013. Data Kependudukan. Jakarta (ID): BPS.

Badan Pusat Statistik. 2017. Data Kependudukan. Jakarta (ID): BPS.

Erfanifar S, Zibaei M, Kasraei M. 2015. Identifying Socioeconomic Factors Affecting theAdoption of Modern Conservation Tillage Technologies in Darab Region. Agricultural Economics and Development 11 (1): 197-203.

Fauzi Y, Widyastuti YE, Satyawibawa I, Paeru RH. 2012. Kelapa Sawit: Budidaya, Pemanfaatan Hasil dan Limbah, Analisis Usaha dan Pemasaran. Jakarta (ID): Penebar Swadaya.

Franz NK, Piercy F, Donaldson J, Westbrook J, Richard R, 2010. Farmer, Agent, and Specialist Perspectives on Preferences for Learning Among Today's Farmers. Journal of Extension 48 (3). [dapat diunduh di https://www.joe.org/joe/ 2010june/rb1.php].

Govindasamy R, Italia J, Adelaja A. 2002. Farmers' Markets: Consumer Trends, Preferences, and Characteristics. Journal of Extension 40 (1). [dapat diunduh di https://www.joe.org/joe/ 2002february/ rb6.php]

Haerani A, Nursyamsi D. 2012. Pengelolaan Air: Kunci Keberhasilan Pertanian Rawa. Banjarbaru (ID): Balai Penelitian Pertanian Lahan Rawa.

Havelock RG. 1969. Planning for Innovation Theory the Dissimination and Utilization of Knowladge. Michigan (US): The University of Michigan.

Helmida BE. 2004. Peranan Program Transmigrasi dalam Meningkatkan Pendapatan Transmigran serta Dampaknya Terhadap Pembangunan Daerah Sekitarnya. Jurnal Valid 1 (1): 65-77.

Ibrahim H, Zain M, Ibrahim T. 2014. Peranan pemimpin lokal dalam meningkatkan kemampuan kelompok. Jurnal Penyuluhan. 10 (1):25-34.

Kaye H. 1997. Mengambil Keputusan Penuh Percaya Diri. Jakarta (ID): Mitra Utama.

Kementerian Tenaga Kerja dan Transmigrasi. 2013. Naskah Akademik Arah dan Kebijakan Ketransmigrasian Tahun 2015-2019. Jakarta (ID): Kemenakertrans RI.

Lippitt R, Watson J, Westley B. 1958. The Dynamics of Planned Change. Harcourt, Brace \& World, Inc.

Lunandi AG. 1993. Pendidikan Orang Dewasa. Jakarta (ID): Gramedia.

Malamassam MA, Surtiari GAK. 2011. Identifikasi Kesesuaian Penduduk Dan Lingkungan di Pulau
Jawa. Di dalam: Suhendra F, Hartiningsih, RW, editor. Pertumbuhan Penduduk dan Kesejahteraan. Jakarta (ID): LIPI Press, hlm 205-231.

Manuwiyoto M. 2004. Mengenal dan Memahami Transmigrasi. Jakarta(ID): Pustaka Sinar Harapan.

Manuwiyoto M. 2008. Transformasi Paradigma Baru Pembangunan Transmigrasi. Jakarta (ID): Pusat Penelitian dan Pengembangan Transmigrasi Departemen Tenaga Kerja dan Transmigrasi.

Mosher AT. 1987. Menggerakkan dan Membangun Pertanian. Krisnadhi S dan Samad B, penerjemah. Jakarta (ID): CV. Yasaguna. Terjemahan dari: Getting Agriculture Moving.

Mubyarto. 2002. Reformasi Agraria: Menuju Pertanian Berkelanjutan. Jurnal Ekonomi Rakyat 1 (8): 2135.

Noor M. 2007. Rawa Lebak: Ekologi, Pemanfaatan, dan Pengembangannya. Jakarta: PT Raja Grafindo Persada.

Noveria M. 2011. Pertumbuhan Penduduk dan Dampaknya Terhadap Kesejahteraan. Di dalam: Suhendra F, Hartiningsih RW, editor. Pertumbuhan Penduduk dan Kesejahteraan. Jakarta (ID): LIPI Press, hlm 1-22.

Oberholtzer L, Dimitri C, Pressman A. 2014. Urban Agriculture in the United States: Characteristics, Challenges, and Technical Assistance Needs. Journal of Extension 52 (6). [dapat diunduh di https://joe.org/joe/ 2014december/a1.php].

Pan D. 2014. The Impact of Agricultural Extension on Farmer Nutrient Management Behavior in Chinese Rice Production: A Household-Level Analysis. Sustainability 6 (1): 44-65.

Padmowihardjo S. 1994. Psikologi Belajar Mengajar. Jakarta (ID): Universitas Terbuka.

Pemerintah Republik Indonesia. 2009. UndangUndang Republik Indonesia Nomor 29 Tahun 2009 tentang Perubahan Atas Undang-Undang Nomor 15 Tahun 1997 tentang Ketransmigrasian. Jakarta (ID): Sekretariat Negara.

Robbins SP. 2001. Perilaku Organisasi: Konsep, Kontroversi, dan Aplikasi. Pujaatmaka $\mathrm{H}$ dan Molan B, penerjemah. Jakarta (ID): Prenhallindo.

Romdiati H, Noveria M. 2002. Mobilitas Penduduk dan Implikasi Sosial Ekonomi di Kabupaten Bolaang Mongondow Provinsi Sulawesi Utara. Jakarta (ID): LIPI.

Rosyid MJ dan Sahuri. 2014. Budidaya Karet Di Lahan Pasang Surut Sumatera Selatan. Prosiding 
Seminar Nasional Lahan Suboptimal; 2014 Sept 26-27; Palembang, Indonesia.

Saksono H. 2011. Kajian Peran Strategis Transmigrasi dalam Implementasi MP3EI. Jurnal Ketransmigrasian 28 (2): 67-77.

Saleh HH. 2005. Transmigrasi: Antara Kebutuhan Masyarakat dan Kepentingan Pemerintah. Jakarta (ID): Pustaka Sinar Harapan.

Salkind NJ. 1989. Theories of Human Development. New York (US): John Willey and Sons.

Slamet M. 2001. Paradigma Baru Penyuluhan Pertanian di Era Otonomi Daerah. Seminar Perhiptani; 2001 Okt 21; Tasikmalaya, Indonesia.

Soekartawi. 2005. Agroindustri dalam Perspektif Sosial Ekonomi. Jakarta (ID): Raja Grafindo Persada.

Sudana W. 2005. Potensi dan Prospek Lahan Rawa sebagai Sumber Produksi Pertanian. Jurnal Analisis Kebijakan Pertanian 3 (2): 141-151.

Suparno S. 2001. Membangun Kompetensi Belajar. Jakarta (ID): Depdiknas.

Tahitu ME. 2013. Kualitas pelayanan penyuluhan pertanian dan kepuasan petani dalam pengembangan usahatani. Jurnal Penyuluhan. 9 (2): 146-155.

Tim Penebar Swadaya. 2008. Panduan Lengkap Karet. Jakarta (ID): Penebar Swadaya.

Tulak PP, Dharmawan AY, Juanda B. 2009. Struktur nafkah rumahtangga petani transmigran. Jurnal Transdisiplin Sosiologi, Komunikasi, dan Ekologi Manusia. 3 (2):203-220.

van den Ban AW, Hawkins HS. 1999. Penyuluhan Pertanian. Jogjakarta (ID): Penerbit Kanisius.

Walker EL. 1973. Kondisi dan Proses Belajar Instrumental. Jakarta (ID): Universitas Indonesia.

Yamin RA. 2017. Teknologi Jalan Ramah Lingkungan Solusi Pembangunan Jalan Berkelanjutan. Seminar Nasional Peranan Teknik Sipil dan Lingkungan untuk Pembangunan Indonesia; 2017 Okt 15; Bogor, Indonesia.

\section{Ucapan Terima Kasih}

Terima kasih diucapkan kepada Direktorat Sumberdaya Ilmu Pengetahuan, Teknologi, dan Pendidikan Tinggi, Kementerian Riset, Teknologi dan Pendidikan Tinggi; atas dukungan dana dari lembaga dimaksud maka penelitian ini terlaksana. 